\title{
Perbedaan Gangguan Psikososial dan Fungsi Kognitif antara Remaja Pendek dengan Indeks Massa Tubuh Rendah dan Normal di Sekolah Menengah Pertama Kota Surakarta
}

Gita Soraya Diananta, Harsono Salimo, Bambang Soebagyo

Bagian Ilmu Kesehatan Anak Fakultas Kedokteran Universitas Sebelas Maret/RSUD Dr. Moewardi, Surakarta

Latar belakang. Perawakan pendek pada anak dan remaja masih sering ditemukan di negara berkembang dan berdampak pada perkembangan fisik, mental dan fungsi kognitif remaja.

Tujuan. Menganalisis perbedaan gangguan psikososial dan fungsi kognitif antara remaja pendek dengan IMT rendah dan normal. Metode. Penelitian observasional dengan desain studi potong lintang yang dilakukan di SMP Negeri 8 dan 20 Kota Surakarta pada bulan Agustus - Oktober 2019 terhadap remaja pendek berusia 11-15 tahun dengan kriteria inklusi dan eksklusi. Pengukuran antropometri berdasarkan WHO 2006 yang dikategorikan sebagai remaja pendek kurus dan pendek normal. Keduanya mengisi kuesioner PSC-17 dan CFIT. Perbedaan gangguan psikososial dan fungsi kognitif antara kedua kelompok dianalisis menggunakan chi square. Hasil penelitian dikatakan bermakna jika nilai $\mathrm{p}<0,05$.

Hasil. Prevalensi remaja pendek adalah $18,5 \%$ terdiri dari remaja pendek kurus (37,5\%) dan pendek normal (62,5\%). Terdapat perbedaan gangguan psikososial dan fungsi kognitif antara remaja pendek kurus dan pendek normal yang bermakna ( $\mathrm{p}=0,007 \mathrm{dan}$ $\mathrm{p}=0,000$ ). Remaja pendek kurus berisiko mengalami gangguan psikososial 2,35 kali dan gangguan fungsi kognitif 8,83 kali. Mayoritas gangguan psikososial adalah masalah internalisasi. Remaja pendek kurus berisiko 2,79 kali ( $\mathrm{p}=0,002)$.

Kesimpulan. Terdapat perbedaan gangguan psikososial dan fungsi kognitif antara remaja pendek dengan IMT rendah dan normal yang secara statistik bermakna. Sari Pediatri 2020;22(3):153-9

Kata kunci: perawakan pendek, remaja, psikososial, kognitif, indeks massa tubuh

\section{The Difference of Pshycosocial Dysfunction and Cognitive Impairment Between Short Stature Adolescents with Low and Normal Body Mass Index in Junior High School Surakarta}

Gita Soraya Diananta, Harsono Salimo, Bambang Soebagyo

Background. Short stature among children and adolescents is often found in developing countries that impacted on physical, mental, and cognitive function.

Objective. Analyze differences in psychosocial dysfunction and cognitive impairment between short stature adolescents with low and normal BMI.

Methods. This cross-sectional study was conducted in 8 and 20 Junior High School Surakarta from August - October 2019 on short stature adolescents aged 11-15 years with inclusion and exclusion criteria. The anthropometric measurement based on the WHO growth chart is classified as low and normal BMI. Both filled the PSC-17 and CFIT questionnaire. The difference was measured by chi-square with $\mathrm{p}$ value $<0.05$ was significantly different.

Result. The prevalence of short stature adolescents is $18.5 \%$ consist of low BMI (37.5\%) and normal BMI (62.5\%). The psychosocial dysfunction and cognitive impairment between short stature adolescents with low and normal BMI were statistically different $(\mathrm{p}=0.007$ and $\mathrm{p}=0.000)$. The short stature adolescent with low BMI is at risk of experiencing in psychosocial dysfunction 2.35 times and cognitive impairment 8.83 times. The majority psychosocial dysfunction is internalization. Underweight short stature adolescent has 2.79 times greater $(\mathrm{p}=0.002)$.

Conclusion. The psychosocial dysfunction and cognitive impairment between short stature adolescents with low and normal BMI were statistically different. Sari Pediatri 2020;22(3):153-9

Keywords: short stature, adolescence, psychosocial, cognitive, body mass index

Alamat korespondensi: Gita Soraya Diananta. Departemen Ilmu Kesehatan Anak Fakultas Kedokteran UNS Gedung Anggrek Lantai 4. Jl.Kolonel Sutarto No.132, Surakarta 57126. Email: gitasd.dr@gmail.com 
$\mathrm{P}$ ertumbuhan normal merupakan salah satu indikator kesehatan anak. Perawakan pendek pada anak dan remaja masih sering ditemukan, khususnya di negara berkembang. Prevalensi perawakan pendek pada anak balita di Indonesia menurut Riskesdas tahun 2016 sebesar 27,6\%. Data remaja dengan perawakan pendek di Indonesia pada tahun 2013 adalah 35,1\%. ${ }^{1-4}$ Perawakan pendek dapat dikategorikan sebagai varian normal dan patologis. Etiologi dari perawakan pendek patologis dapat disebabkan oleh malnutrisi, gangguan endokrin, maupun kelainan genetik. Penyebab perawakan pendek karena malnutrisi kronis, infeksi berulang, dan kurang stimulasi disebut stunting. Adanya mutasi pada gen tertentu seperti mutasi pada gen ACAN, FBN1, COL9A2, IGF1R dapat menimbulkan manifestasi klinis perawakan pendek pada bayi hingga remaja. ${ }^{1,5,6}$

Remaja merupakan masa transisi antara anak menjadi dewasa. Pada masa ini terjadi pacu tumbuh berat badan dan tinggi badan. Selain itu juga terjadi perkembangan kematangan psikososial dan timbulnya tanda seks sekunder. Salah satu indikator pertumbuhan normal seorang remaja dapat dinilai berdasarkan indeks masa tubuh menurut usia sesuai dengan grafik WHO atau CDC 2000. Postur tubuh seorang remaja kurus, normal, atau gemuk dapat memengaruhi cara pandang remaja terhadap diri dan lingkungan sekitarnya. Oleh karena itu, perubahan bentuk tubuh sangat berpengaruh pada kehidupan kejiwaan remaja. Remaja pendek juga berisiko mengalami gangguan fungsi kognitif yang lebih besar dibandingkan remaja normal. , $^{4,-10}$

Salah satu dampak perawakan pendek pada remaja adalah hambatan perkembangan fisik dan mental yang dapat berpengaruh terhadap fungsi kognitif. Remaja dengan perawakan pendek biasanya mengalami keterbatasan fisik, perilaku bermasalah, bullying (diejek dan diganggu), kesulitan untuk membangun hubungan interpersonal. Di samping itu, remaja juga akan mengalami permasalahan psikososial, seperti harga diri rendah, cenderung mempunyai perilaku menghindar, mengalami kecemasan, adanya perasan bersalah dan depresi. Hal tersebut akan berdampak pada penurunan kemampuan belajar, masa studi yang lebih lama, penurunan kapasitas bekerja, memengaruhi produktivitas kerja dan dapat mengakibatkan penghasilan yang rendah saat beranjak dewasa. ${ }^{11,12}$

Terdapat alat ukur untuk mendeteksi terjadinya masalah psikososial pada remaja. Salah satunya adalah pediatric symptoms checklist (PSC). Alat ukur PSC digunakan untuk mengukur masalah psikososial, mental emosional, dan gangguan perilaku. Alat ukur ini dikelompokkan dalam 3 masalah, yaitu atensi, internalisasi, dan eksternalisasi. Instrumen pengukuran fungsi kognitif untuk remaja bermacam-macam. Salah satunya adalah pemeriksaan IQ dengan kuesioner culture fair intelligence test (CFIT) yang dikembangkan oleh Raymond B. Cattel. Kuesioner ini dapat mengukur kemampuan intelegensi mulai usia 4 tahun. Kuesioner CFIT merupakan salah satu metode pengukuran fungsi kognitif non verbal terhadap kemampuan analisis dalam situasi abstrak dan termasuk aspek pemahaman visual spasial. ${ }^{13,14}$

Data penelitian tentang gangguan psikososial dan fungsi kognitif pada remaja perawakan pendek masih belum banyak dilakukan. Oleh karena itu, penelitian ini diharapkan dapat menyajikan data tentang prevalensi remaja dengan perawakan pendek dan menganalisis gangguan psikososial dan fungsi kognitif pada remaja pendek serta perbedaan gangguan psikososial dan fungsi kognitif pada remaja pendek dengan indeks masa tubuh yang rendah dan normal.

\section{Metode}

Penelitian ini merupakan penelitian observasional dengan desain studi potong lintang. Penelitian ini dilakukan di SMP Negeri 8 dan SMP Negeri 20 Kota Surakarta pada bulan Agustus - Oktober 2019. Kriteria inklusi adalah remaja pendek berusia 11-15 tahun, bersedia menandatangani lembar persetujuan penelitian dan sedang tidak sakit saat pengisian kuesioner. Kriteria eksklusi adalah remaja yang menderita penyakit kronis seperti tuberkulosis paru, penyakit jantung bawaan, penyakit hormonal, dan talasemia; remaja dengan kelainan cacat bawaan seperti CTEV atau kelainan tulang belakang (lordosis, skoliosis, maupun kifosis); remaja dengan sindrom tertentu; remaja dengan disabilitas intelektual. Penelitian ini telah memperoleh kelaikan etik dari Komisi Etika Penelitian Kesehatan (KEPK) Rumah Sakit Dr. Moewardi dan mendapat persetujuan dari Dinas Pendidikan Kota Surakarta.

Dilakukan pengukuran antropometri kepada semua siswa di kedua sekolah menggunakan kurva WHO 2006. Alasan pemilihan kurva WHO pada penelitian ini karena merupakan hasil pengamatan jangka panjang anak-anak dari berbagai negara di empat benua yang asupan nutrisi serta lingkungannya 
ideal untuk tumbuh kembang anak. ${ }^{2}$ Remaja pendek didefinisikan tinggi badan/usia kurang dari -2 SD kuva WHO 2006. Pengukuran berat badan menggunakan digital weighing scale SECA ${ }^{\mathrm{TM}}$ dengan ketelitian hingga $0,01 \mathrm{~kg}$ yang telah dikalibrasi. Pengukuran tinggi badan menggunakan alat microtoice dengan ketelitian $0,1 \mathrm{~cm}$. Remaja yang termasuk kelompok pendek kemudian dilakukan pengukuran indeks massa tubuh dan diplotkan berdasarkan kurva BMI WHO 2006. Remaja dengan indek massa tubuh yang rendah didefinisikan sebagai rasio berat badan terhadap tinggi badan menurut usia berada kurang dari -2 SD. Remaja pendek dengan indeks massa tubuh rendah kemudian disebut remaja pendek kurus dan remaja dengan indeks massa tubuh normal disebut remaja pendek normal. Baik remaja pendek kurus maupun normal diberikan penjelasan penelitian dan menandatangani persetujuan penelitian lalu diberikan kuesioner yang berisi tentang data usia, jenis kelamin, pendidikan, pekerjaan orangtua, data karakteristik lingkungan keluarga, sekolah, dan teman sebaya. Remaja tersebut juga mengisi kuesioner PSC-17 dan dilakukan pengukuran tes IQ menggunakan kuesioner CFIT. Pengukuran antropometri dilakukan oleh asisten peneliti dengan alasan objektifitas. Pengukuran tes IQ dilakukan oleh Psikolog dari RS Dr. Moewardi Surakarta.

Data yang diambil tersebut dimasukkan ke dalam program perangkat lunak SPSS ${ }^{\oplus} 24$. Karakteristik subyek penelitian meliputi data jenis kelamin, usia, pendidikan dan pekerjaan orangtua, tingkat penghasilan keluarga, karakteristik lingkungan keluarga, sekolah, dan teman sebaya disajikan dalam bentuk tabel. Perbedaan gangguan psikososial dan fungsi kognitif remaja pendek disajikan dalam bentuk tabel dan dianalisis menggunakan chi square. Hasil penelitian dikatakan bermakna jika didapatkan nilai $\mathrm{p} \leq 0,05$.

\section{Hasil}

Jumlah siswa di SMP Negeri 8 dan SMP Negeri 20 Surakarta adalah 1106 siswa. Saat pengambilan data 39 siswa yang tidak masuk sehingga tersisa 1067 remaja yang dilakukan pengukuran antropometri. Dari 1067 siswa tersebut, 197 (18,5\%) siswa termasuk remaja pendek. Terdapat 33 remaja yang dieksklusi karena tidak lengkap mengisi kuesioner dan termasuk disabilitas intelektual. Subyek penelitian yang dianalisis 164 remaja, terdiri dari 74 remaja pendek kurus dan 90 pendek normal.
Tabel 1 menunjukkan adanya perbedaan yang secara statistik bermakna antara kelompok remaja pendek kurus dan pendek normal dalam hal pekerjaan ayah, tingkat pendidikan ayah, dan tingkat sosial ekonomi. Usia remaja pada remaja pendek kurus 13-14 tahun dan 12-13 tahun pada remaja pendek normal. Jenis kelamin terbanyak pada remaja pendek kurus adalah lelaki $(58,1 \%)$ sedangkan remaja pendek normal adalah perempuan $(66,7 \%), \mathrm{p}=0,001$.

Tabel 2 menunjukkan adanya perbedaan gangguan

Tabel 1. Karakteristik subyek penelitian

\begin{tabular}{|c|c|c|c|c|c|}
\hline \multirow[t]{3}{*}{ Karakteristik } & \multicolumn{4}{|c|}{ Kelompok remaja } & \multirow[t]{3}{*}{ nilai $\mathrm{p}$} \\
\hline & \multicolumn{2}{|c|}{$\begin{array}{l}\text { Pendek } \\
\text { kurus } \\
(\mathrm{n}=74)\end{array}$} & \multicolumn{2}{|c|}{$\begin{array}{c}\text { Pendek } \\
\text { normal } \\
(\mathrm{n}=90)\end{array}$} & \\
\hline & $\mathrm{F}$ & $\%$ & $\mathrm{~F}$ & $\%$ & \\
\hline Jenis kelamin & & & & & $0,001^{*}$ \\
\hline Laki-laki & 43 & 58 & 30 & 33 & \\
\hline Perempuan & 31 & 42 & 60 & 67 & \\
\hline Usia (tahun) & & & & & 0,434 \\
\hline $12-13$ & 26 & 35 & 38 & 42 & \\
\hline $13-14$ & 31 & 42 & 29 & 32 & \\
\hline$>14$ & 17 & 23 & 23 & 26 & \\
\hline Pekerjaan ayah & & & & & $0,020^{*}$ \\
\hline PNS & 12 & 16 & 15 & 17 & \\
\hline Non PNS & 37 & 50 & 61 & 68 & \\
\hline Lain-lain & 25 & 34 & 14 & 16 & \\
\hline Pekerjaan ibu & & & & & 0,353 \\
\hline PNS & 5 & 7 & 2 & 2 & \\
\hline Non PNS & 11 & 15 & 13 & 14 & \\
\hline Lain-lain & 58 & 78 & 75 & 84 & \\
\hline Pendidikan ayah & & & & & $0,000^{*}$ \\
\hline SD & 23 & 31 & 8 & 9 & \\
\hline SMP & 2 & 3 & 16 & 18 & \\
\hline SMA & 20 & 27 & 31 & 34 & \\
\hline Perguruan tinggi & 29 & 39 & 35 & 39 & \\
\hline Pendidikan ibu & & & & & 0,198 \\
\hline $\mathrm{SD}$ & 24 & 32 & 17 & 19 & \\
\hline SMP & 10 & 14 & 14 & 16 & \\
\hline SMA & 26 & 35 & 43 & 48 & \\
\hline Perguruan tinggi & 14 & 19 & 16 & 18 & \\
\hline $\begin{array}{l}\text { Tingkat sosial } \\
\text { ekonomi }\end{array}$ & & & & & $0,021^{*}$ \\
\hline$\geq 1,8$ juta & 31 & 42 & 54 & 60 & \\
\hline$<1,8$ juta & 43 & 58 & 36 & 40 & \\
\hline
\end{tabular}

Keterangan : Uji chi square/Fischer;

*) Signifikan pada $\alpha=5$ 
Gita Soraya Diananta dkk: Perbedaan gangguan psikososial dan fungsi kognitif antara remaja pendek dengan IMT rendah dan normal

Tabel 2. Perbedaan gangguan psikososial dan fungsi kognitif remaja pendek kurus dan pendek normal

\begin{tabular}{lccc}
\hline Gangguan/Masalah & $\begin{array}{c}\text { Pendek } \\
\text { kurus } \\
(\mathrm{n}=74)\end{array}$ & $\begin{array}{c}\text { Pendek } \\
\text { normal } \\
(\mathrm{n}=90)\end{array}$ & nilai p \\
\hline $\begin{array}{c}\text { Fungsi kognitif (\%) } \\
\text { Di bawah normal }\end{array}$ & $53(72)$ & $20(22)$ & OR=8,83 \\
$\quad$ Normal & $21(28)$ & $70(78)$ & \\
Psikososial (\%) & & & $0,007^{*}$ \\
Ya & $46(62)$ & $37(41)$ & OR=2,35 \\
Tidak & $28(38)$ & $53(59)$ & \\
Internalisasi (\%) & & & $0,002^{*}$ \\
Ya & $44(59)$ & $31(42)$ & OR=2,79 \\
Tidak & $30(41)$ & $59(58)$ & \\
Eksternalisasi (\%) & & & 0,491 \\
Ya & $11(15)$ & $10(11)$ & \\
Tidak & $63(85)$ & $80(89)$ & \\
Perhatian (\%) & & & 1,000 \\
Ya & $7(10)$ & $8(9)$ & \\
Tidak & $67(90)$ & $82(91)$ & \\
\hline
\end{tabular}

Keterangan : Uji chi square/Fischer;

*) Signifikan pada $\alpha=5$

psikososial dan fungsi kognitif antara remaja pendek kurus dan pendek normal ( $\mathrm{p}=0,007$ dan $\mathrm{p}=0,000$ ). Remaja pendek kurus berisiko mengalami gangguan psikososial 2,35 kali dan gangguan fungsi kognitif sebesar 8,83 kali. Gangguan psikososial yang paling banyak ditemukan adalah masalah internalisasi, kelompok remaja pendek kurus berisiko 2,79 kali dibandingkan remaja pendek normal $(\mathrm{p}=0,002)$.

Dalam hal karakteristik lingkungan keluarga tidak didapatkan perbedaan yang secara statistik bermakna antara kedua kelompok (Tabel 3). Pola asuh antara kedua kelompok sebagian besar adalah demokratis. Baik kelompok remaja pendek kurus maupun pendek normal sebagian besar tidak mempunyai masalah keluarga.

Pada karakteristik lingkungan sekolah, terdapat perbedaan yang secara statistik bermakna antara kelompok remaja pendek kurus dan pendek normal dalam hal kesulitan belajar $(\mathrm{p}=0,000)$, suasana sekolah yang mendukung $(\mathrm{p}=0,000)$, bermasalah dengan guru $(\mathrm{p}=0,004)$, dan keikutsertaan dalam organisasi di sekolah $(p=0,015)$. Remaja pendek kurus lebih banyak mengalami kesulitan belajar dibandingkan dengan remaja pendek normal. Jumlah remaja pendek kurus yang mengikuti kegiatan organisasi di sekolah lebih sedikit jika dibandingkan dengan remaja pendek
Tabel 3. Karakteristik lingkungan keluarga

\begin{tabular}{lccccc}
\hline & \multicolumn{3}{c}{ Kelompok remaja } & nilai p \\
\cline { 2 - 4 } & \multicolumn{2}{c}{$\begin{array}{c}(\mathrm{n}=74) \\
\text { Lingkungan Keluarga }\end{array}$} & $\begin{array}{c}\text { Pendek } \\
\text { normal } \\
(\mathrm{n}=90)\end{array}$ \\
\cline { 2 - 5 } & $\mathrm{F}$ & $\%$ & $\mathrm{~F}$ & $\%$ & \\
\hline Jumlah saudara & & & & & 0,786 \\
$\leq 2$ & 24 & 32 & 31 & 34 & \\
$>2$ & 50 & 68 & 59 & 66 & \\
Bercerita dengan keluarga & & & & 0,271 \\
Ya & 31 & 42 & 44 & 51 & \\
Tidak & 43 & 58 & 43 & 49 & \\
Pola asuh & & & & & 0,936 \\
Ambisius & 8 & 11 & 8 & 9 & \\
Demokratis & 48 & 65 & 62 & 69 & \\
Otoriter & 10 & 13 & 11 & 12 & \\
Permissif & 4 & 5 & 3 & 3 & \\
Membandingkan & 4 & 5 & 6 & 7 & \\
Masalah Keluarga & & & & & 0,300 \\
Ya & 31 & 42 & 45 & 50 & \\
Tidak & 43 & 58 & 45 & 50 & \\
Kedekatan saudara kandung & & & & 0,510 \\
Ya & 34 & 46 & 46 & 51 & \\
Tidak & 40 & 54 & 44 & 49 & \\
\hline
\end{tabular}

Keterangan : Uji chi square/Fischer;

*) Signifikan pada $\alpha=5$

normal. Terdapat perbedaan yang bermakna antara kelompok remaja pendek kurus dan pendek normal dalam hal keikutsertaan dalam kelompok "geng" tertentu $(\mathrm{p}=0,004)$, bercerita dengan teman dekat $(\mathrm{p}=0,000)$, dan perasaan tidak percaya diri $(\mathrm{p}=0,000)$. Jumlah remaja pendek kurus yang merasa tidak percaya diri lebih banyak dibandingkan dengan remaja pendek normal.

\section{Pembahasan}

Prevalensi remaja dengan perawakan pendek adalah $18,5 \%$ dan pendek kurus $74(37,5 \%)$ orang. Jumlah ini lebih banyak dibandingkan penelitian sebelumnya yang dilakukan oleh Faisal dkk ${ }^{15}$ pada 302 remaja di Kabupaten Karawang, didapatkan 10,3\% remaja pendek dan $1,7 \%$ remaja sangat pendek. Usia remaja pada penelitian kami adalah 13-14 tahun untuk kelompok pendek kurus dan 12-13 tahun untuk kelompok pendek normal, sejalan dengan penelitian oleh Faisal ${ }^{15}$ dan Erfanti, ${ }^{16}$ yaitu 13 tahun dan 13,2 tahun. 
Gita Soraya Diananta dkk: Perbedaan gangguan psikososial dan fungsi kognitif antara remaja pendek dengan IMT rendah dan normal

Kami mendapatkan perbedaan bermakna antara remaja pendek kurus dibandingkan remaja pendek normal berdasarkan jenis kelamin. Remaja pendek kurus sebagian besar remaja lelaki yaitu 58,1\%. Penelitian oleh Melaku ${ }^{17}$ melaporkan bahwa prevalensi pendek dan kurus lebih banyak pada remaja lelaki dibandingkan perempuan. Hal ini diduga karena stadium percepatan pertumbuhan antara remaja lelaki dan perempuan berbeda. Remaja perempuan lebih cepat memulai dan selesai pacu tumbuh dibandingkan lelaki.

Terdapat perbedaan gangguan fungsi kognitif antara remaja pendek dengan indeks masa tubuh rendah dan normal. Fungsi kognitif ditentukan berdasarkan hasil tes IQ. Pada penelitian kami, remaja pendek kurus berisiko 8,83 kali memiliki tes IQ di bawah normal jika dibandingkan dengan remaja pendek normal. Hal ini sejalan dengan penelitian yang dilakukan oleh Tarigan $\mathrm{dkk}^{4}$ tahun 2017 pada 45 remaja pendek di Pangandaran. Pada penelitian tersebut 19 anak memiliki gangguan fungsi kognitif ringan sebanyak 19 anak dan 1 dengan gangguan fungsi kognitif berat. ${ }^{4}$ Salah satu efek jangka panjang dari pendek kurus adalah gangguan fungsi kognitif dan kesulitan belajar di sekolah. ${ }^{18}$

Setiap anak dengan perawakan pendek kurus perlu dicurigai karena kondisi malnutrisi kronis sehingga perlu dilakukan pelacakan lebih lanjut tentang etiologinya. Suatu kondisi malnutrisi diduga dapat memengaruhi perkembangan anak melalui proses defek pada serabut mielin saraf, proliferasi pada sinaps saraf atau inflamasi pada sel saraf. Hal ini dapat mengakibatkan anak mengalami kesulitan dalam mengikuti pelajaran di sekolah sehingga menyebabkan anak terlambat dan tidak naik kelas. ${ }^{12,20}$ Hal tersebut sejalan dengan hasil penelitian kami, 40,5\% remaja pendek kurus memiliki kesulitan dalam belajar, lebih banyak dibandingkan remaja pendek normal yang hanya $7,8 \%$ mengalami kesulitan belajar. Pada uji statistik, didapatkan perbedaan bermakna dalam hal kesulitan belajar antara remaja pendek kurus dan pendek normal.

Menurut Galler $\mathrm{dkk}^{12}$ terdapat suatu hubungan antara nutrisi, inflamasi, dan faktor individu serta lingkungan pada remaja di negara berkembang. Kondisi malnutrisi, pertumbuhan linier yang terganggu, pendek, dan kurus pada remaja dapat menyebabkan gangguan perkembangan pada struktur otak, defisit kognitif, kemampuan mengendalikan diri dan berperilaku, kesulitan belajar dan pencapaian prestasi yang rendah di sekolah, kurang percaya diri, kurang keterampilan dan kemampuan berinteraksi interpersonal serta keterampilan parenting yang berlanjut antar generasi. Hasil penelitian ini sejalan dengan yang disebutkan oleh Galler dkk. Kondisi malnutrisi menyebabkan remaja pendek dan kurus memiliki tes IQ yang lebih rendah sehingga mengalami kesulitan belajar di sekolah. Di samping itu pula, masalah internalisasi juga menyebabkan remaja kurang percaya diri.

Kami mendapatkan perbedaan gangguan psikososial pada remaja pendek dengan IMT rendah dibandingkan normal. Remaja pendek kurus berisiko 2,35 kali terjadi gangguan psikososial. Hal ini sejalan dengan penelitian Erfanti $\mathrm{dkk}^{16}$ tahun 2016 yang melaporkan remaja dengan severely stunted memiliki kecenderungan untuk terjadi gangguan psikososial 6,33 kali daripada remaja dengan tinggi badan pendek normal. Pada penelitian tersebut juga dilaporkan bahwa remaja pendek mempunyai fungsi psikososial yang lebih buruk daripada remaja dengan tinggi badan normal. ${ }^{16}$ Penelitian lain oleh Himaz ${ }^{20}$ di India tahun 2017 melaporkan bahwa remaja pendek usia 12-19 tahun memiliki masalah dalam hubungan dengan teman sebaya dibandingkan dengan remaja yang tidak pendek. Penelitian serupa oleh Xuan dkk ${ }^{21}$ tahun 2017 juga melaporkan bahwa remaja pendek memiliki fungsi psikososial yang lebih rendah dibandingkan oleh remaja dengan tinggi normal.

Gangguan psikososial paling banyak ditemukan pada aspek internalisasi. Pada penelitian kami, remaja pendek kurus memiliki kecenderungan untuk terjadi masalah internalisasi 2,79 kali daripada remaja pendek normal. Sejalan dengan penelitian yang dilakukan oleh Quitmann $\mathrm{dkk}^{22}$ di Belanda tahun 2016 pada anak dan remaja perawakan pendek usia 4-18 tahun. Quitmann melaporkan bahwa anak dan remaja dengan perawakan pendek berisiko terjadinya masalah psikososial, terutama masalah internalisasi. Masalah internalisasi mencakup gangguan kecemasan, ketakutan, dan gangguan suasana hati seperti depresi. Pada remaja pendek kecenderungan memiliki tingkat kepercayaan diri yang rendah, merasa minder dan depresi karena riwayat pem-bully-an dan menarik diri dari pergaulan. Gangguan psikopatologi yang dapat muncul pada remaja pendek, antara lain, gangguan cemas, depresi, gangguan perilaku, dan gangguan bipolar. ${ }^{16}$

Postur tubuh seorang remaja kurus, normal, atau gemuk dapat memengaruhi cara pandang remaja terhadap diri dan lingkungan sekitarnya sehingga perubahan bentuk tubuh sangat berpengaruh pada kehidupan kejiwaan remaja. ${ }^{9}$ Kami mendapatkan jumlah remaja pendek kurus cenderung memiliki 
rasa kurang percaya diri lebih banyak dibandingkan dengan remaja pendek normal. Hasil uji statistik menunjukkan terdapat perbedaan bermakna dalam hal perasaan kurang percaya diri antara remaja pendek kurus dibandingkan remaja pendek normal.

Kami nendapatkan bahwa remaja pendek kurus cenderung introvert, tidak suka bercerita kepada teman dekat maupun keluarga serta tidak termasuk dalam kelompok teman sebaya tertentu. Selain itu, remaja pendek kurus cenderung sedikit mengikuti kegiatan organisasi di sekolah. Kami mendapatkan perbedaan perihal keikutsertaan dalam organisasi sekolah antara remaja pendek kurus dibandingkan remaja pendek normal. Hal ini sejalan dengan penelitian Erfanti $\mathrm{dkk}^{16}$ yang melaporkan 53 remaja dengan gangguan psikososial dari 100 orang sampel remaja perawakan pendek, $17 \%$ di antaranya mengalami kurang percaya diri.

Tidak didapatkan perbedaan bermakna aspek eksternalisasi maupun perhatian antara remaja pendek kurus dan pendek normal. Akan tetapi, terdapat 11 dan 7 remaja pendek kurus memiliki kecenderungan masalah eksternalisasi dan perhatian. Sejalan dengan penelitian yang dilakukan Rahmadi $\mathrm{dkk}^{23}$ pada remaja usia 9-11 tahun di Brebes didapatkan adanya masalah perilaku abnormal $27 \%$ pada remaja dengan perawakan pendek. Pada penelitian tersebut didapatkan prevalensi gangguan emosional dan perilaku pada remaja perawakan pendek lebih banyak dibandingkan pada remaja normal.

Tingkat sosial ekonomi keluarga menjadi salah satu faktor yang memengaruhi terjadinya gangguan psikososial. Pada penelitian ini didapatkan sebagian besar remaja pendek kurus termasuk dalam tingkat sosial ekonomi kurang. Hal ini sejalan dengan penelitian Erfanti $\mathrm{dkk}^{16}$ yang melaporkan gangguan psikososial remaja dihubungkan dengan status sosial ekonomi keluarga. Status sosial ekonomi menjadi salah satu faktor risiko terjadinya masalah psikososial pada anak dan remaja.

Kami menemukan bahwa tingkat pendidikan ayah dan ibu pada remaja pendek kurus cenderung lebih rendah. Pendidikan ayah dan ibu pada remaja pendek kurus untuk tingkat SD lebih tinggi dibandingkan remaja pendek normal. Tingkat pendidikan orang tua membentuk pola asuh mereka dalam mendidik anak. Ibu dengan tingkat pendidikan rendah cenderung untuk tidak dapat mengatasi stres. Tingkat pendidikan ayah dapat memengaruhi pendapatan keluarga sehingga berhubungan dengan status sosial ekonomi di lingkungan. Keluarga dengan status sosial ekonomi kurang, cenderung merasa cemas dan depresi sehingga menyebabkan kualitas pola asuh rendah. Hal ini dapat memicu gangguan perilaku pada remaja. ${ }^{24,25}$

Keterbatasan pada penelitian kami adalah tidak dibedakan penyebab perawakan pendek pada remaja apakah termasuk kategori varian normal atau patologis. Tidak dilakukan analisis pada kelompok remaja pendek gemuk. Selain itu, jenis masalah internalisasi yang muncul tidak dilakukan analisis lebih lanjut. Kebaruan pada penelitian ini selain jumlah subyek penelitian yang lebih banyak dari penelitian sebelumnya, dilakukan analisis lebih spesifik yaitu remaja pendek kurus dibandingkan remaja pendek normal. Berdasarkan temuan kami diketahui bahwa meskipun sama - sama pendek, remaja pendek kurus lebih berisiko terjadi gangguan psikososial dan fungsi kognitif dibandingkan dengan remaja pendek normal.

\section{Kesimpulan}

Terdapat perbedaan gangguan psikososial dan fungsi kognitif antara remaja pendek dengan IMT rendah dan normal. Remaja pendek kurus memiliki 8,83 kali risiko hasil IQ di bawah normal dibandingkan remaja pendek normal. Remaja pendek kurus berisiko 2,35 kali mengalami gangguan psikososial dibandingkan remaja pendek normal. Gangguan psikososial yang paling banyak adalah masalah internalisasi (59,5\%). Remaja pendek kurus berisiko 2,79 kali terjadi masalah internalisasi dibandingkan remaja pendek normal.

\section{Daftar pustaka}

1. Julia M. Pendekatan diagnosis stunting dan perawakan pendek lainnya. Dalam 7th Indonesian Pediatric Endocrinology Update Gangguan hormonal pada anak dan remaja dalam praktek sehari - hari. Jakarta: UKK Endokrinologi-IDAI; 2019.h.25-9.

2. Hendarto A, Syarif DR. Antropometri anak dan remaja. Dalam: Sjarif DR, Lestari ED, Mexitalia M, Nasar SS, penyunting. Buku ajar nutrisi pediatrik dan penyakit metabolik. Jilid 1 revisi. Jakarta: Badan Penerbit IDAI; 2014.h.25-40.

3. Kementrian Kesehatan Republik Indonesia. Profil kesehatan Republik Indonesia (riskesdas). Jakarta: Kementrian Kesehatan Republik Indonesia; 2017. 
Gita Soraya Diananta dkk: Perbedaan gangguan psikososial dan fungsi kognitif antara remaja pendek dengan IMT rendah dan normal

4. Tarigan R, Dhamayanti M, Fadlyana E, Rusmil K. Different result of cognitive impairment screening in adolescent aged 10-12 years with normal and short stature in Pangandaran District. Am J Clin Med Res 20175;3:26-30.

5. Batubara JR, Tjahjono HA, Aditiawati. Perawakan pendek pada anak dan remaja di Indonesia. Dalam: Panduan praktek klinis ikatan dokter anak Indonesia. Jakarta: Badan penerbit IDAI; 2017.

6. Yue S, Whalen P, Jee YH. Genetic regulation of linier growth. Annals Pediatric Endocrinol Metabolism 2019;24:2-14.

7. Soetjiningsih. Tumbuh kembang remaja. Dalam: Soetjiningsih, Ranuh IGR, penyunting. Tumbuh kembang anak. Edisi ke-2. Jakarta: EGC; 2002.h.116-124.

8. Marheni A. Perkembangan psikososial dan kepribadian remaja. Dalam: Soetjiningsih, penyunting Tumbuh Kembang Remaja dan permasalahannya.. Jakarta. Sagung seto; 2004.h.45-52.

9. Primaningtyas W, Putri AAA, Hastuti H. Body image and religiosity in adolescents: a comparation between public and private high school students. Smart Med J 2019;2:98-103.

10. Kementrian kesehatan Republik Indonesia. Peraturan Menteri Kesehatan Republik Indonesia nomor 2 tahun 2020 tentang standar antropometri anak. Jakarta : Kementrian Kesehatan Republik Indonesia; 2020.

11. Ashworth, A. Nutrition, food security, and health. Dalam: Kliegman RM, Stanton BF, Schor NF, Behrman RE, St.Gene III JW, penyunting. Nelson textbook. Pediatr.20th ed.;Philadelphia: Elsevier Inc; 2016.h.295-306.

12. Galler JR, Koethe JR, Yolken RH. Neurodevelopment : the impact of nutrition and inflammation during adolescence in low-resource settings. Pediatrics 2017;139:71-81.

13. Pujiastuti E, Fadlyana E, Garna H. Perbandingan masalah psikososial pada remaja obes dan gizi normal menggunakan pediatric symptom checklist (PSC-17). Sari Pediatri 2013;15:201-6.

14. Nur'aeni. Tes psikologi: tes intelegensi dan tes bakat. Yogyakarta: Pustaka Pelajar; 2012.h.35-42.

15. Faisal, Reniarti L, Andriana N. Hubungan status pubertas dengan stunting pada anak siswi SD dan SMP Kecamatan Tempuran Kabupaten Karawang. Diunduh pada 30 September 2020. Didapat dari: www.journal.unpad.ac.id.

16. Erfanti DO, Setiabudi D, Rusmil K. The relationship of psychosocial dysfunction and stunting of adolescents in Suburban, Indonesia. J Med Psychol 2016;5:57-65.

17. Melaku YA, Zello GA, Gill TK, Adams RJ, Shi Z. Prevalence and factors associated with stunting and thinness among adolescent students in Northern Ethiopia :a comparison to World Health Organization standarts. Bio Med Central 2015;73:1-11.

18. Christian P, Smith ER. Adolescents undernutrition : Global burden, physiology, and nutritional risks. Ann Nutr Metab 2018:72:316-28.

19. Measelle J. Neurodevelopmental effects of stunting. Diunduh pada 30 September 2020. Didapat dari : https://cpb-us-e1. wpmucdn.com/blogs.uoregon.edu/dist/9/10007/files/2016/03/ Measelle_Brain_Malnutrition-FinalShare-10nlx9r.pdf.

20. Himaz, Rosana. Stunting later in childhood and outcomes as a young adult : Evidence from India. Elsevier 2018;104:344-57.

21. Xuan XU, Jie WEN, Dan-Xia PENG, Yuan LIU. Quality of life in children with short stature: analysis using PedsQL. CJCP 2013;10:870-4.

22. Quitmann JH, Bullinger M, Sommer R, Rohenkohl AC, Da Silva NM. Associations between psychological problems and quality of life in pediatric short stature from patient's and parent's perspectives. PloS ONE 2016;11:1-20.

23. Rahmadi FA, Hardaningsih G, Pratiwi R. Prevalensi dan jenis masalah emosional dan perilaku pada anak usia 9-11 tahun dengan perawakan pendek di Kabupaten Brebes. Jurnal Gizi Indonesia 2016;3:116-9.

24. Fauzi R, Chasbulloh RR, Tama IY. Pengaruh pola asuh anak terhadap perilaku menyimpang pada usia remaja. Jurnal.uns. ac.id 2019:2:360-5.

25. Victoria CG, Adair L, Fall C, dkk. Maternal and child undernutrition: consequences for adult health and human capital. Lancet 2008;371:340-57 